日泌尿会誌, 87 巻, 2 号, 1996 年 : 158 165

\author{
SP - 1 泌尿器科医を対象としたインフォームドコンセントに関するアンケート調盛 \\ 岡山大学 \\ 津島知靖，那須良次，野田雅俊，秋山道之進，真鍋大輔，公文裕已，大森弘之
}

最近，インフォームドコンセント（IC）への関心が医師および患者の間で高まっている。したがって，基礎 資料として IC に関する泌屎器科医の現在の考え方を把握することは重要である。今回，岡山大学㧍よび関連病 院に勤務する医師を対象としてアンケート調査を行なったので報告する。

89 名を対象にアンケートを送付し. 64 名（71.9\%）から回答が得られた。どのような患者にICを行なって いますかの設問に対しては，全ての患者に対してが 35\%，ほとんどの患者に対してが 40\%であった。治瘺可能 な患者に対する癌の告知に関しては，原則的に告知するが $48 \%$ ，患者の意志を確認し告知が $14 \%$ であり，まず

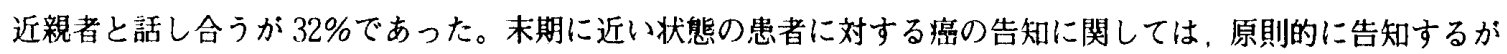

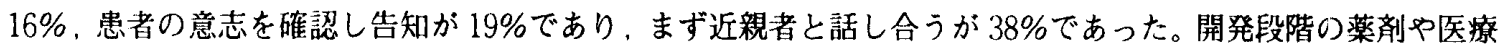
器械の治験に関しては，中立的な立場で説明し，治験参加は患者の意志に任せているが $37 \%$ ，樌栫的に治験参 加をお顆いし，同意を得ているが37\%であり，治験であることは㖟昧にして同意を得るが 11\%で沾った。無作 為制付け比較試験では，無作為割付けであることを事前に説明するが $25 \%$ ，当該疾患に対する一般的な治療法 を祱明し，患者が治療法の選択を医師に委ねた場合には無作為割付けにより決定された治療法を説明し同意を

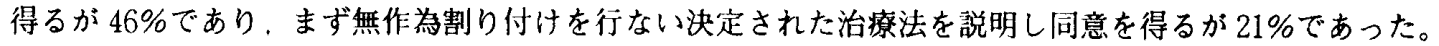

今回のアンケート調查により，泌尿器科医がICに高い関心を示していることが䇲われた。癌の告知に関して は，治療可能な症例に対してはよく告知がなされているが，末期に近い患者に対して告知する医師の割合は低 かった。また，臨床治験に関してはよく説明がなされているが，無作為割付け比較試験において唓作為割付け であることを事前に説明している医師は少なかった。

\title{
SP - 2 関西医科大学淰尿器科学教室における度告知の現犾
}

\section{関西医科大学"}

川喜多繁誠"、岡田日佳"、小山泰樹"、三上 修"、川村 博”、松田公志"

土井俊邦 ${ }^{21} 、$ 室田卓之"2、大原 孝" 、雨堤賢一"

【目的】インフォームド・コンセントが一般常識となり、一般市民にも疾に対する知識が增えている現 在、告知の問題は癌治癔における主要なテーマの1つである。今回我々はアンケートを用いることに より当教室における䖵告知の現状を調査すると共に今後の方向につき考察した。

【方法】関西医科大学泌尿器科学教室教室貣21名に対して遇去3年間に担当した痁患者への告知状況につ いてアンケート調査を実施した。

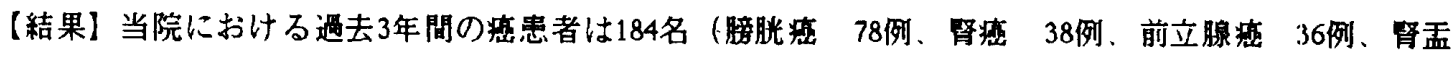

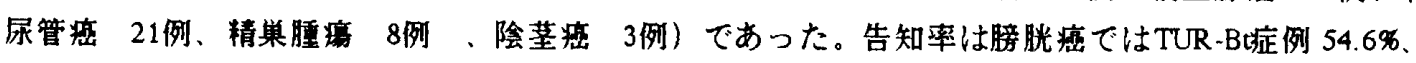
Cystectomy症例 65.0\%、Chemotherapy症例 27.5\%、根治不能症例 $26.1 \%$ 、堅㿋ではNephrectomy症例 $40.0 \%$ 、根治不能症例 19.0\%、前立腺癌ではProstatectomy症例 75.0\%、Hormone therapy症例 36.4\%、精巣腫痹で はstage 1 症例 86.4\%、Chemotherapy症例 93.9\%、根治不能症例 44.5\%であった。

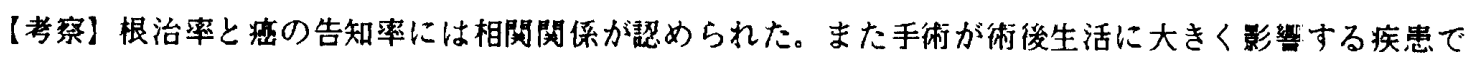
は告知率が高かった。 